\title{
磁気記録用メタル磁性粉の開発について
}

\author{
鈴木 明杄，笠原 美幸计2 \\ 动1 関東電化工業秼新製品開発本部, 干100 千代田区丸，内1-2-1. \\ 出2 関東電化工業侏記録材料研究所, 干 377 涉川市金井 425.
}

\section{Development of Metal Powder for Magnetic Recording}

\author{
Akira Suzuki ${ }^{\hat{\kappa} 1}$ and Miyuki Kasahara ${ }^{2} 2$ \\ $\$ 1$ New Products Development Division, Kanto Denka Kogyo Co., Ltd., 1-2-1 Marunouchi Chiyoda-ku, Tokyo \\ 100. $\star^{2}$ Magnetic Materials laboratory, Kanto Denka Kogyo Co., Ltd., 425 Kanai, Shibukawa 377.
}

Received February 9, 1995

\section{SYNOPSIS}

The metal powder first used in the audio field (around 1980) had an Hc value of 1100 to $12000 \mathrm{e}$, and a particle length of $0.5 \mu \mathrm{m}$. Since audio systems have not changed, the situation is basically the same today, but improvements are constantly being made in electromagnetic conversion and coating characteristics. With the development of eightmillimeter video, the characteristics of metal powder changed significantly, with an Hc value of $15000 \mathrm{e}$ and a particle length as small as $0.3 \mu \mathrm{m}$ (around 1985). With the development of high-band eight-millimeter video around 1990, the degree of fineness was further improved, with an Hc value of $16000 \mathrm{e}$ and a particle length of $0.2 \mu \mathrm{m}$ being achieved.

Current metal powder has an Hc value of 1700 to 18000 e and a particle length of 0.15 $\mu \mathrm{m}$. With the development of next-generation systems already underway, even greater degrees of fineness and higher $\mathrm{Hc}$ and $\sigma s$ values are being demanded. As time pass on, the realization of characteristics, such as $0.1 \mu \mathrm{m}$ in length and $20000 \mathrm{e}$, will soon become an accomplished fact.

KEY WORDS

Metal powder, Hc value, Particle length, $\sigma$ s value.

\section{1 磁気記録システムの進歩}

磁気記録の歴史は1890年の Poulsenの鋼線を使っ た録音機に始まるがい，1940年頃（昭和15年）には 現在の磁気記録の基本になる磁気ヘッドおよび記録 媒体の形が確立された（ドイツ）。

実際に，第二次世界大戦下のドィッでは，これが 実用化され，その音質も大变良いものであった.

ここでは，磁気郡録の歴史を振りかえるのではな
いので、メタル磁性粉に関係する部分をながめてみ たい.

1.1 オーディオ分野

1962年（㗁和37年）以降オーディオ分野で，それ までのオープンリール式テープレコーダーに替わっ て、フィリップス社が開発したコンパクトカセット が使われ出した. このコンパクトカセットの音質を 高めるため,メタルポシション付のデッキが1978年 
Table 1 History of the magnetic recording system

\begin{tabular}{|c|c|c|c|}
\hline Year & Aud io & VTR for consumer use & VTR for professional use \\
\hline 1900 & 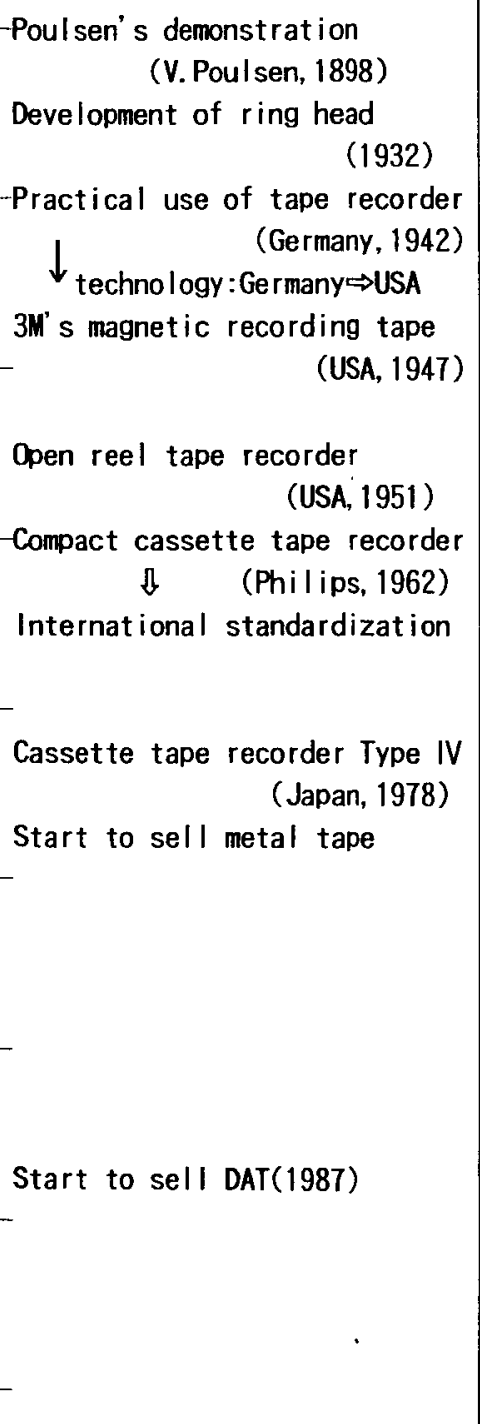 & 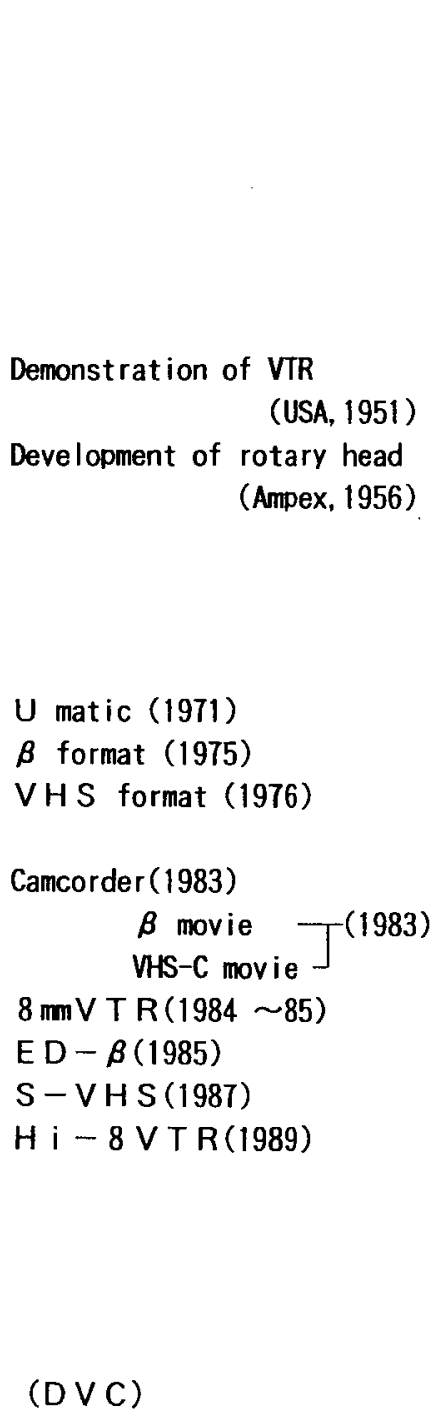 & $\begin{array}{l}U \text { matic(1971) } \\
C \text { format(1977) } \\
M \text { format(Matsushi ta, 1981) } \\
\beta \text {-cam(Sony, 1981) } \\
M \| \text { (Matsushita, 1985) } \\
\beta \text {-cam-SP(Sony, 1986) } \\
D-2 \text { (Sony, 1988) } \\
D-3 \text { (Matsushita, 1991) } \\
D-\beta \text {-cam(Sony, 1993) } \\
D-5 \text { (Matsushita, 1994) }\end{array}$ \\
\hline
\end{tabular}

秋に発表された（ビクター）。これに使われたテー プが米国スリーエム社のものであった.

私共関東電化は，その数年前からメタル磁性粉の 開発を進めており，このメタル対応デッキの発売に 合わせて工業生産に踏み切った。

このメタルテープの特徽は, 保磁力 $(\mathrm{Hc})$ と磁束密 度(Br)が大きいことによる高出力の再現性の良さ， 高域特性の良さでありました。

基本的な記䟿システムは，同じコンパクトカセッ
トでありますので, 密度化と云う観点からみると， メタル磁性粉の特性をひき出したものではなかった とも云えますが，メタルが持つ高エネルギーを音質 と音量で示した点とメタル磁性粉が実用的に使用に 耐え得ることを諗知して貴うための第一歩であり， その後，数年は，映像分野への展開のため，準備期 間として，粉，テープ両面からの改良が行われた。

1.2 民生用VTR分野

メタルテープが使われる前, 映像分野で使用され 
Table 2 Performance of the VTR system for consumer use.

\begin{tabular}{|c|c|c|c|c|}
\hline & $\begin{array}{l}\text { Tape width }(\mu \mathrm{m}) \\
\text { Particle }\end{array}$ & $\stackrel{* \lambda}{(\mu \mathrm{m})}$ & $\begin{array}{l}\text { Recording density } \\
\left(\mu \mathrm{m}^{2} / \mathrm{bit}\right)\end{array}$ & $\begin{array}{l}\text { Horizontal } \\
\text { resolution }\end{array}$ \\
\hline$\beta$ & $\begin{array}{l}1 / 2 \text { inch } \\
\mathrm{Co}-\gamma-\mathrm{Fe}_{2} \mathrm{O}_{3}\end{array}$ & 1. 45 & 42.5 & 240 \\
\hline VHS & $\begin{array}{l}1 / 2 \mathrm{inch} \\
\mathrm{Co}-\gamma-\mathrm{Fe}_{2} \mathrm{O}_{3}\end{array}$ & 1. 32 & 38.2 & 240 \\
\hline $8 \mathrm{~mm} \vee \mathrm{VTR}$ & Met a I & 0.70 & 7. 18 & 250 \\
\hline$E D-\beta$ & $\begin{array}{l}1 / 2 \mathrm{inch} \\
\mathrm{Metal}\end{array}$ & 0.75 & 20.2 & 500 \\
\hline$S-V H S$ & $\begin{array}{l}1 / 2 \text { inch } \\
\mathrm{Co}^{-} \boldsymbol{\gamma}-\mathrm{Fe}_{2} \mathrm{O}_{3}\end{array}$ & 0.83 & 24.0 & 430 \\
\hline $\mathrm{H} i-8$ & $\begin{array}{c}8 \mathrm{~mm} \\
\mathrm{Met} \mathrm{al}\end{array}$ & 0.49 & 5. 02 & 430 \\
\hline
\end{tabular}

Table 3 Performance of the VTR system for professional use.

\begin{tabular}{|c|c|c|c|c|}
\hline & $\begin{array}{l}\text { Tape width }(\mu \mathrm{m}) \\
\text { Particle }\end{array}$ & $\stackrel{* \lambda}{(\mu \mathrm{m})}$ & $\begin{array}{l}\text { Recording density } \\
\qquad\left(\mu \mathrm{m}^{2} / \mathrm{bit}\right)\end{array}$ & $\begin{array}{c}Y-S / N \\
(d B)\end{array}$ \\
\hline$U$ matic & $\begin{array}{l}3 / 4 \text { inch } \\
\mathrm{CO}^{-} \gamma+\mathrm{Fe}_{2} \mathrm{O}_{3}\end{array}$ & 1. 90 & 130 & - \\
\hline$C$ format & $\begin{aligned} 1 & \text { inch } \\
\mathrm{Co}^{-} & \gamma-\mathrm{Fe}_{2} \mathrm{O}_{3}\end{aligned}$ & 2. 56 & 230 & 48 \\
\hline$M$ format & $\begin{array}{l}1 / 2 \text { i n c h } \\
\mathrm{Co}^{-} \gamma-\mathrm{Fe}_{2} \mathrm{O}_{3}\end{array}$ & 0.95 & 135 & - \\
\hline$\beta-c$ a $m$ & $\begin{array}{l}1 / 2 \text { inch } \\
\mathrm{Co}^{-} \gamma-\mathrm{Fe}_{2} \mathrm{O}_{3}\end{array}$ & 1. 08 & 87 & 48 \\
\hline$M-\|$ & $\begin{array}{l}1 / 2 \text { i n ch } \\
M e t \text { a l }\end{array}$ & 1.01 & 22.2 & 49 \\
\hline$\beta$-cam-SP & $\begin{array}{l}1 / 2 \text { i n c h } \\
\mathrm{Met} \text { a l }\end{array}$ & 0.90 & 38.7 & 51 \\
\hline$D-2$ & $\begin{array}{l}3 / 4 \mathrm{inch} \\
\mathrm{Metal}\end{array}$ & 0.85 & 16.6 & 54 \\
\hline$D-3$ & $\begin{array}{l}1 / 2 \text { i } \mathrm{nch} \\
\mathrm{Met} \mathrm{al}\end{array}$ & 0.77 & 7.7 & 54 \\
\hline$D-\beta$-cam & $\begin{array}{l}1 / 2 \mathrm{i} \mathrm{Ch} \\
\mathrm{Metal}\end{array}$ & 0.69 & 7. 5 & 62 \\
\hline$D-5$ & $\begin{array}{l}1 / 2 \mathrm{i} \mathrm{nch} \\
\mathrm{Metal}\end{array}$ & 0.64 & 6.4 & 62 \\
\hline
\end{tabular}

* The shortest recording wave length of magnetic recording media. 
ていたシステムをみますと，民生用としてベータと VHS，業務用としてCーフォーマット， Mーフォ ーマット，ベータカムがあり，磁性材料としてはコ バルト変性 $\gamma-\mathrm{Fe}_{2} 0_{3}$ であった.

民生用ビデオはテレビの録画が中心の据圈型であ ったが，1983年ベータムービー，VHSムービーと カメラ一体型V T Rが登場する。ほぼ同時にカメラ 一体型 8 ミリビデオの世界統一規格が承認され, 続 いて発表された．（1984年〜85年）特に 8 ミリビデ オの発表で，テレビ録画あるいはビデオの再生専用 の据固型とは異なる新しい市場が産み出されたもの と云えます。

これに使用されたテープの保磁力 $(\mathrm{Hc})$ は $15000 \mathrm{e}$, 最短記録波長で $0.70 \mu \mathrm{m}$ であり，オーディオのメ夕 ルテープの最短記録波長2. $37 \mu \mathrm{m}(\mathrm{Hc}=1200 \mathrm{0e})$ から 一挙に短くなりました。

ビデオの面記録密度で比較しますと，ベータ，V $\mathrm{H} \mathrm{S}$ の面記録密度 $40 \mu \mathrm{m}^{2} / \mathrm{bitから} 8$ ミリビデオ 7.18 $\mu \mathrm{m}^{2} / \mathrm{bitc}$ 高密度化された. 続いて，1989年（平成 元年） 8 ミリビデオはハイバンド化され，高画質化 された. $\mathrm{H} \mathrm{i}-8$ の面記録密度は $5.02 \mu \mathrm{m}^{2} / \mathrm{b}$ itとな り，画質も水平解像度 430 本と放送電波の 330 本を 上迴るものとなった。

\section{3 業務用 V T R 分野}

8 ミリビデオ発売と同じ年（1985年），業務用 V T RはそれまでのMーフォーマット，ベータカムに 替り、メタルテープを使用した $\mathrm{M}$ Iおおびベータカ ムS P が発売され，記録密度が向上した（MII $22.2 \mu \mathrm{m}^{2} / \mathrm{bit}$, ベータカムS P $38.7 \mu \mathrm{m}^{2} / \mathrm{bit}$ )

8 ミリビデオがハイバンド化される前後，業務用 VTRは相次いでデジタル化が行われ，記録密度， 画質共に急速に向上しつつある.

\section{4 データストレージ分野}

オーディオ分野でのデジタルシステムとして, 1987年（昭和62年）DATが発売された。 その最短

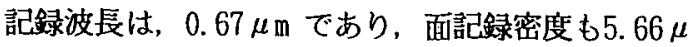
$\mathrm{m}^{2} /$ bitと高いものである.

このDATはオーディオ用途以外にデータストレ 一ジ用としての用途があり，DD Sと称されている. この分野でもシステムの改良が進められており，最

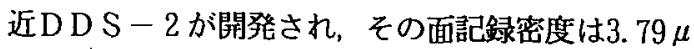

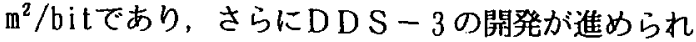
ている.

また， 8 ミリビデオのデータストレージもあり，
米国エクサバイト社の開発によるものである.これ ら磁気記録システムは，小型軽量化と高音質，高画 質および長時間化を求めて改良されており，そのテ 一プに使用されるメタル磁性粉はより微細化, 高Hc

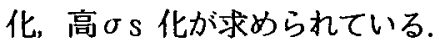

\section{2 メタル䃄性粉の製法}

メタル磁性粉の製法は種々検討されてきたが，現 在ではオキシ水酸化鉄の針状粒子を原料とする方法 で行われている2.3)。

プロセスとしては(1) オキシ水酸化鉄の合成工程 (酯化工程)，(2）烧結防止剂を被着させる表面処理 工程，（3）才キシ水酸化鉄を $\alpha$ 一酸化鉄にする仮姺 工程，（4）還元工程，（5）安定化工程から成る. 2.1 才キシ水酸化鉄（ゲーサイト）の合成工程 オキシ水酸化鉄は出発原料の硫酸第一鉄もしくは 塩化第一鉄水溶液をアルカリで中和して，グリーン ラストを生成させ，このスラリー液に空気を吹き込 むことにより，針状のオキシ水酸化鉄を製造する.

この工程でメタル磁性粉の基本的特性を支配する 粒子の大きさ，形状が決まる. 従って、均一で微細 なメタル磁性粉を得るにはこの工程の管理が重要で ある。

\section{2 表面処理工程}

（1）で合成した針状オキシ水酸化鉄をそのまま逶 元すると，針状粒子が焼結して，形状がくずれ、ま た粒子同士でも焼結が生じるため，保磁力 $(\mathrm{Hc})$ ，角 型の低いメタル粉になる.この現象を防ぐために， 針状才キシ水酸化鉄粒子の表面にSi，Al，B などの 化合物を均一に被着させる.

\section{3 仮泋工程}

表面好理を施した針状オキシ水酸化鉄を 500 $700^{\circ} \mathrm{C}$ 高温で処理して粒子の焼き緔めを行う。こ の処理により還元後に得られる粒子は空孔が少なく 形状の良いものとなる.

\section{4 還元工程}

$\alpha-\mathrm{Fe}_{2} \mathrm{O}_{3}$ は $400 \sim 600^{\circ} \mathrm{C}$ で水素ガスで還元する ことにより，容易にメタル化するが，この反忘のポ イントの一つは生成する水の影響である.この反応 如可逆反忍であり，生成する水の分姫が高くなる之 反応が阻害され，同時に生成メ夕ル粉の物性にも影 響する.

\section{5 安定化工程}

還元したままのメタル粉は非常に活性であり，空 


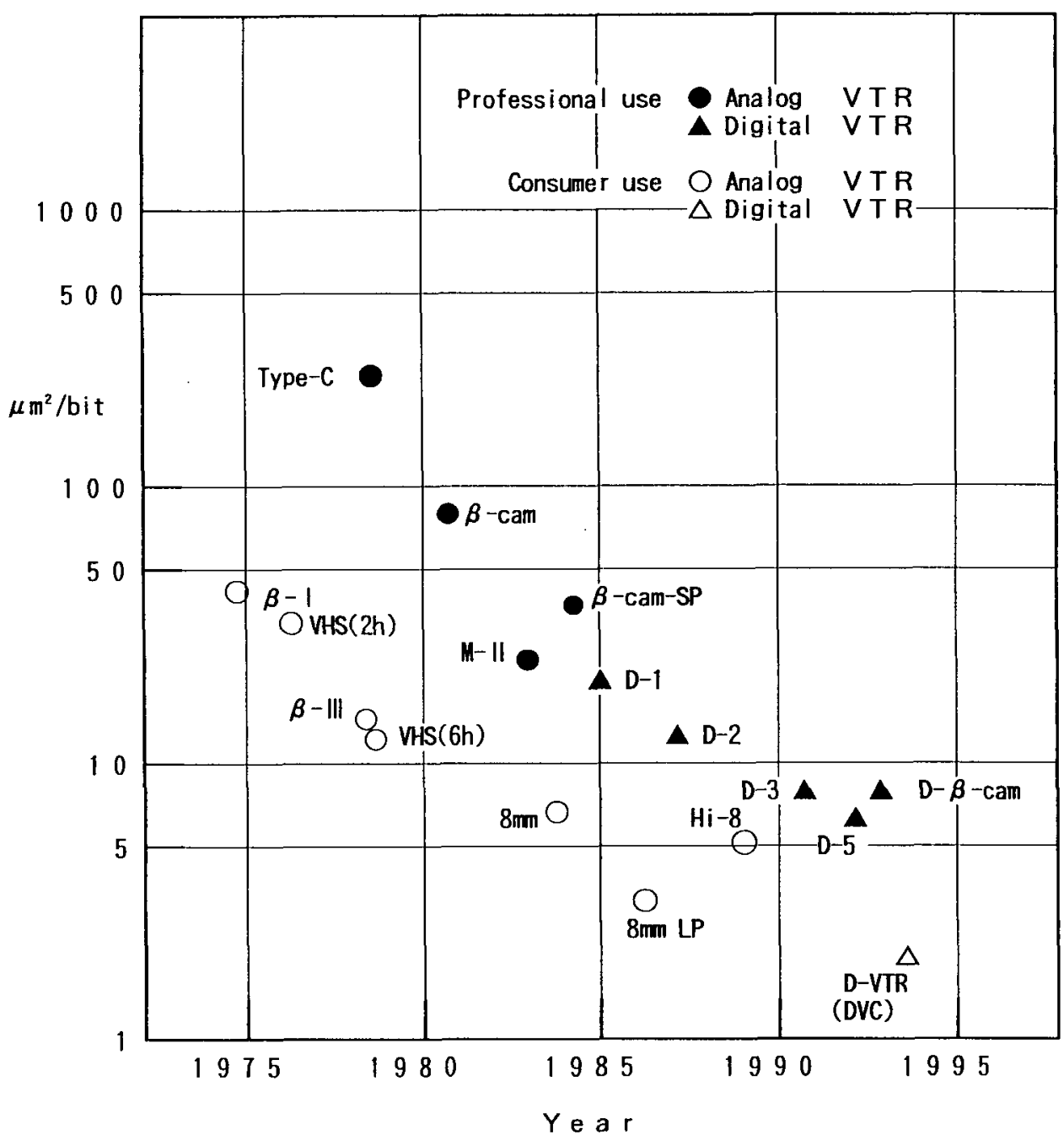

Fig. 1 Advancement of the recording density for the magnetic recording system with the change of the times.

気中に取り出すと急激な酸化反吣により燃姺してし まう。そこで空気中に取り出す前に，メタル粉粒子 の表面に薄い酸化皮膜を形成させて, 空気中で安全 に取り扱えるようにする．安定化方法としては大別 して次の二つの方法に分類される.

(1)有機溶剤中で酸化皮膜を形成させる方法（液相 安定化法)

例えば活性なメタル粉をトルエンに浸漬し，その 中に酸素濃度をコントロールして空素ガスを吹き 込み，粒子表面を徐々に酸化し酸化皮膜を形成さ せる.
(2)還元後の活性なメタル粉に，直接微量な酸素を 含有する窒素ガスを通し，徐々に酸化皮膜を形成 させる方法.（気相安定化法）

(1)の方法で製造したメタル羒の表面には，メタル粉 が酸化触媒亡なって生成したトルエンの酸化生成物 が付着しており，(2)で製造した有機物の付着の無い メタル粉と比較すると酸化安定性（一定条件下にお ける $\sigma \mathrm{s}$ の降下率) が劣るため，最近では(2)で製造 したメタル粉が指向されている. しかし(1)で製造し たメタル粉も，メタル粉の $\sigma \mathrm{s}$ が高くとれること, および塗料化時のバインダーとのマッチングの関係 
で好まれる場合もある。

\section{$3 \times$ メ磁性粉の特性制御}

\section{1 保磁力 $(\mathrm{Hc})$}

一般には形状磁気異方性と結晶磁気異方性をコン トロールすることにより，保持力を变化させている. 先にも述べたが、メタル羒の北状は出発原料である オキシ水酸化鉄の形状でほぼ決まるので，この形状 を制御することが重要.

メタル磁性粉の形状としてはその長径 $(\ell)$ と短 径 (d)の比 $(\ell / d)$ と保磁力 (Hc) との間にFig. 2 の

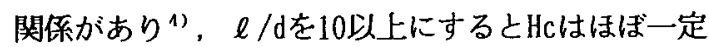
となるが，大きすぎると塗料特性が悪くなる。

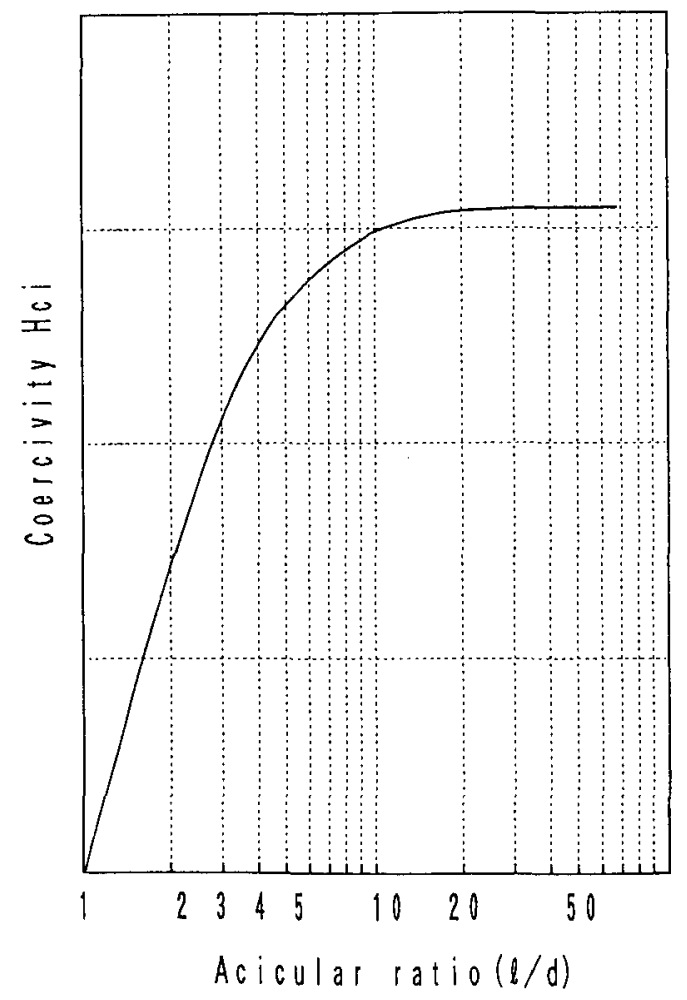

Fig. 2 Variation of coercivity Hci with acicular ratio.

また，粒径（短径）之保磁力 $(\mathrm{Hc})$ との関係におい ては，或る範围迄は粒径を小さくすることによりHc が上がる傾向である. Meiklejhon及びLuborskyは鉄 微粒子についての测定結果をPig. 3 のように示して
おり，粒径 $200 \AA$ 付近に最大值が存在する ${ }^{5, ~(6) . ~}$

更にメタル磁性粉はその製法から判るように，才 キシ水酸化鉄の脱水，還元時の脱水之，脱水反応が 起こり，粒子内に多くの空孔が存在する. そのため, 単磁区樓造がくずれ，Hcが下がるので，粒子の橔密 化は欠かせないものである.

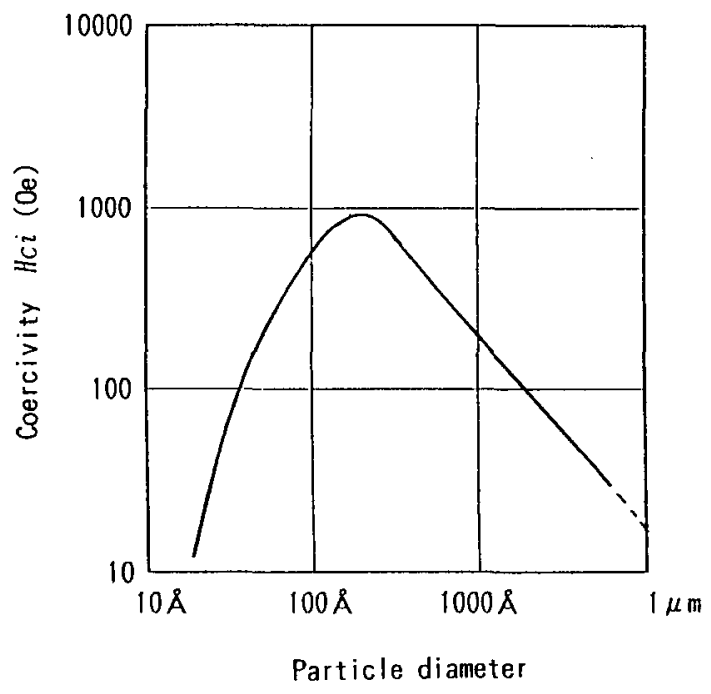

Fig. 3 Variation of coercivity with particle diameter for pure iron at $76^{\circ} \mathrm{K}$.

\section{2 磁化力 ( $\sigma \mathrm{s})$}

純鉄の $\sigma \mathrm{s}$ は218emu/gであるが，実用的にはメ夕 ル粉の $\sigma \mathrm{S}$ は 100 150emu/gである.これは筅結防 止剂等の磁化力の無い添加物による希瀵効果と, メ タル粉の表面の酸化皮膜の生成によるものである. 従って, 添加物の減少, 酸化皮膜の薄膜化で当然 $\sigma$ $\mathrm{s}$ は向上する.

一般的に行われる $\sigma \mathrm{s}$ の向上手段としては，コバ ルト添加によるメタル粉の合金化があり, SlaterPauling曲線7) あるいは Weiss及びForrerの测定" (Fig.4）によればコバルト30\%前後で最大となる. 


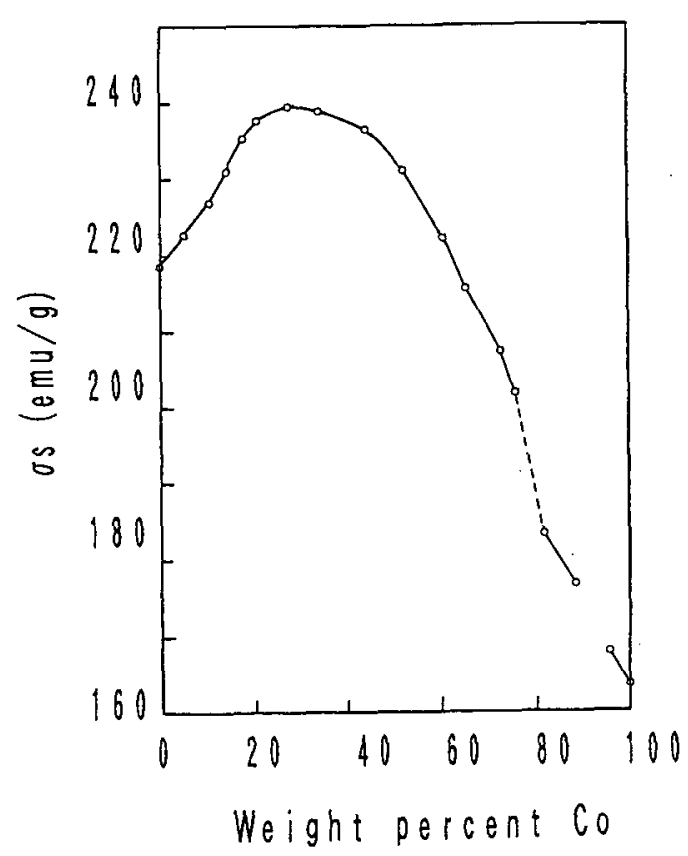

Fig. 4 Variation of $\sigma \mathrm{s}$ at room temperature with compositon of iron-cobalt alloy.

\section{3 求められるその他の特性}

\section{3 .1 微細化}

高Hc化のためにも微細化が必要であるが，低ノイ ズ化，及び，短波長記録のため，今後特に要求され る.これの制御はオキシ水酸化鉄合成工程で行うも のであるが，得られた微細粉を還元，安定化するの もまた，苦労するところである.

さらに，微細になる程，此表面積が増大し，粒子 中の酸化皮膜の占める割合が多くなり，磁化が小さ くなる.

\subsection{2 粒子の均一化}

粒子が不均一では，Hcも不均一となり，その結果， SPDが悪く，消去特性が劣化する。この制御もオキ シ水酸化鉄合成工程で行うものである.

\subsection{3 酸化安定性}

酸化安定性の良いメタル物を作るには表面の酸化 皮膜を強固にすれば良いが，酸化皮膜を厚くすれば， $\sigma \mathrm{s}$ が低下するので, そのバランスが重要であり，

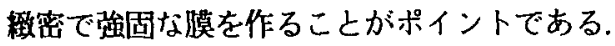

\section{3 .4 分散性}

塣料化の際の分散性は極めて重要なファクターで あり，表面処理剤の影謷，オキシ水酸化鉄合成の際 の条件，その他各工程の諸条件が絵合的に埧響する
ので，最も神経を使う部分である.

\section{4 メタル磁性粉の進步}

オーディオ用メタルデープは世に出てすでに 15 年を経ておりますが，当初のオーディオメタル粉と 現在使用されているオーディオメタル羒を較べると， かなり改良されているが，システムが同じであるの で，基本的な特性は変わりがない.

ビデオ用についても，同じことが云えます．

各システムに対応したメタル磁性粉の進歩を粉の Hc，粒径，比表面積（SSA），の変化でたどってみる と，システムの記録密度の向上と共に使用されるメ タル粉のHcは上がり，粒径は小さくなっている，す なわち，オーディオ用の $\mathrm{Hc}=1100 \mathrm{Oe}$, 粒径 $0.5 \mu \mathrm{m}$ のものが 8 ミリビデオを中心とした用途のものでは, $\mathrm{Hc}=1500 \mathrm{Oe}$, 長径 $0.3 \mu \mathrm{m}$ になり, 更にH i -8 で は, $\mathrm{Hc}=16000 \mathrm{e}$, 長径 $0.2 \mu \mathrm{m}$. 最近開発されたシス テムでは, $\mathrm{Hc}=1700 \sim 18000 \mathrm{e}$, 長径 $0.15 \mu \mathrm{m}$ 以下へ と改良されてきている。

一方，比表面積(SSA) は微粒子化が進むにつれ大 きくなるが，最近の粉では，逆に小さくなる傾向が みられる.これは粉の緻密化とか, 表面処理方法の 工夫等によるものである.

次のシステムに要求されるメタル粉は，Hc= $20000 \mathrm{e}$ 以上, 長径 $0.1 \mu \mathrm{m}$ 以下であり, その開発が 進められている.

\section{文献}

1) Marvin camras : MAGNETIC RECORDING HANDBOOK, P. 1.

2)鈴木新太郎，木暮宗吉，守谷好美，狩野勝：日本 国特評登録 NNo.1284806.

3)A. A. Van der Giessen : IEEE Trans Magn., MAG5(1973).

4) 饭田修一，桜井良文，岩崎俊一，長鴄富雄, 岩間義郎，渡辺昭治，小林寛著: 硬質磁性材料

5)W. H. Meiklejohn : Rev.Mod. Phy., 25 (1953) 302.

6)F. E. Luborsky, T. 0. Paine : J.App 1. Phys., 31 (1960)68s.

7)R. M. Bozorth : Ferromagnet ism. P. 441.

8)K. Hoselitz : Ferromagnetic properties of Metals and Alloys. P. 317. 